\title{
Maximal toxicity of cloned CytA $\delta$-endotoxin from Bacillus thuringiensis subsp. israelensis requires proteolytic processing from both the $\mathbf{N}$ - and C-termini
}

\author{
Said A. S. Al-yahyaee $\nmid$ and David J. Ellar \\ Author for correspondence: David J. Ellar. Tel: +44 1223 333651. Fax: +44 1223333345. \\ e-mail: DJE1@MOLE.BIO.CAM.AC.UK
}

Department of Biochemistry, University of Cambridge, Tennis Court Road, Cambridge CB2 1QW, UK

\begin{abstract}
Unlike the CytA toxin from native Bacillus thuringiensis subsp. israelensis (Bti) crystals, the inclusions of cloned CytA produced by Bti IPS 78/11 in the presence of the $20 \mathrm{kDa}$ 'helper' protein require a reducing agent in addition to a highly alkaline pH for complete solubilization. Activation of the solubilized CytA with a range of proteases produced 25-22 kDa products. SDS-PAGE analysis and $\mathrm{N}$-terminal amino acid sequencing revealed that CytA was processed very similarly at both termini by proteinase $K$ or by Anopheles or Culex gut extracts. Trypsin, by contrast, processed CytA predominantly at the $\mathbf{N}$-terminus. In vitro cytolytic assays against Aedes aegypti cells, and haemolytic assays against rat erythrocytes, showed that CytA processed at both termini by proteinase $K$ was the most active form. Thus CytA, like other Bt $\delta$-endotoxins, is processed to a well-defined protease-resistant product and this processing enhances the toxicity in vitro and possibly in vivo.
\end{abstract}

Keywords: Bacillus thuringiensis, $\delta$-endotoxins, CytA, haemolytic assay

\section{INTRODUCTION}

The crystalline inclusions produced by Bacillus thuringiensis subsp. israelensis (Bti) (Goldberg \& Margalit, 1977) have been shown by SDS-PAGE to contain four different proteins (Tyrell et al., 1981; Thomas \& Ellar, 1983). These four proteins were designated CytA, CryIVD, CryIVB and CryIVA, with molecular masses of 27, 65, 135 and $128 \mathrm{kDa}$, respectively (Hofte \& Whiteley, 1989). The most abundant of the four is Cyt $A$, which constitutes $40 \%$ of total crystal protein. Thomas \& Ellar (1983) partially solubilized CytA by incubating the crystals with $50 \mathrm{mM} \mathrm{Na}{ }_{2} \mathrm{CO}_{3} / \mathrm{HCl}\left(\mathrm{pH} \mathrm{10.5)}\right.$, for $30 \mathrm{~min}$ at $37^{\circ} \mathrm{C}$. When the alkali-solubilized protein was assayed against various cell lines and erythrocytes, it showed a broad in vitro cytolytic and haemolytic activity.

Armstrong et al. (1985) solubilized CytA from native Bti crystals by incubating them in deionized water brought to $\mathrm{pH} 12$ with $\mathrm{NaOH}$ for $3 \mathrm{~h}$ at $37^{\circ} \mathrm{C}$. The solubilized product was then treated with trypsin for $2 \mathrm{~h}$ followed by proteinase $\mathrm{K}$ for another $2 \mathrm{~h}$ at $37^{\circ} \mathrm{C}$. This activation

†Present address: Department of Biochemistry, College of Medicine, Sultan Qaboos University, PO Box 35, Al-Khod 123, Sultanate of Oman.

Abbreviation: Bti, Bacillus thuringiensis subsp. israelensis. regime produced a $25 \mathrm{kDa}$ protease-resistant protein. After purification, this $25 \mathrm{kDa}$ protein was shown to be active against mosquito cell lines and erythrocytes as well as being lethal to 6-week-old BALB/c mice when $100 \mu \mathrm{g}$ was injected intraperitoneally. A similar study was reported by Gill et al. (1987) who, in addition to the $25 \mathrm{kDa}$ protein, purified a $24 \mathrm{kDa}$ protein which was antigenically similar and had an identical N-terminus. Both proteins lysed human erythrocytes and cultured mosquito cells, the $24 \mathrm{kDa}$ protein being the more toxic.

Chilcott \& Ellar (1988) employed partial solubilization as described by Thomas \& Ellar (1983) and Mono Q ionexchange chromatography to purify the $27 \mathrm{kDa} C y t A$ from Bti crystals; the preparation was then treated with trypsin and reapplied to the Mono $Q$ column. The trypsintreated product was eluted with $10-600 \mathrm{mM} \mathrm{NH}_{4} \mathrm{HCO}_{3}$ (pH 8.5) and shown to have a molecular mass of $25 \mathrm{kDa}$. This purified product was similar in size and properties to that reported by Armstrong et al. (1985) and Gill et al. (1987).

The cloning of the cyt $A$ gene (Ward et al., 1984) and subsequent expression in B. subtilis (Ward et al., 1986) and acrystalliferous Bti IPS 78/11 (Crickmore et al., 1990) made it possible to obtain pure CytA crystals, which were shown by Ward et al. (1986) to be alkali soluble and active 
against mosquito cell lines and erythrocytes with the same $\mathrm{LC}_{50}$ value as CytA derived from native Bti $\delta$-endotoxin crystals. When the solubilized product was activated with Aedes aegypti gut extract it retained toxicity against mosquito cell lines and erythrocytes (Ward et al., 1988).

Soluble Cyt A, unlike CytB (Knowles et al., 1992; Koni \& Ellar, 1994) or Cry toxins (Hofte \& Whiteley, 1989) is probably active without prior processing. However, the high susceptibility of the CytA N-terminus to endogenous proteases hindered previous attempts to assay the unprocessed CytA. In this paper we show that the $\mathrm{N}$ terminal processing of $\mathrm{Cyt} A$ by endogenous proteases can be minimized by solubilizing $\mathrm{Cyt} A$ at $\mathrm{pH} 12$. We also show the relative contribution of the $\mathrm{N}$-terminal processing and the $\mathrm{N}$-terminal and $\mathrm{C}$-terminal processing to CytA cytolytic activity.

\section{METHODS}

Bacterial strain, media and growth conditions. The Bt strain used was subspecies israelensis IPS $78 / 11$ harbouring the cyt $A$ gene and the $20 \mathrm{kDa}$ 'helper' protein gene (Crickmore et al., 1990). The strain was grown to late exponential phase in LuriaBertani (LB) broth or on LB agar plates (Sambrook et al., 1989) at $30^{\circ} \mathrm{C}$, overnight. For synchronous sporulation, IPS 78/11 was grown in casein/casein/yeast extract (CCY) broth (Stewart et al., 1981) for $24-36 \mathrm{~h}$ using a $0 \cdot 1 \%$ inoculum of cell culture grown to exponential phase in $5 \%$ peptone, $0 \cdot 1 \%$ yeast extract, $0.5 \% \mathrm{NaCl}$ (PWYE) from a heat-shocked spore suspension (Ellar \& Posgate, 1974). For the selection of plasmids encoding chloramphenicol acetyltransferase, $5 \mu \mathrm{g}$ chloramphenicol ml $\mathrm{m}^{-1}$ was included.

Purification and solubilization of CytA inclusions. The Cyt A inclusions were purified as described by Thomas \& Ellar (1983). Briefly, the spore-crystal mixture was initially washed with icecold deionized water to remove the cell debris. The pellet was then resuspended in Tris/ $\mathrm{KCl}$ buffer $(50 \mathrm{mM}$ Tris/ $\mathrm{HCl}, 10 \mathrm{mM}$ $\mathrm{KCl}, \mathrm{pH} 7.5$ ) and layered onto a discontinuous sucrose density gradient of 67,72 and $79 \%(\mathrm{w} / \mathrm{v})$ sucrose made up in Tris $/ \mathrm{KCl}$ buffer. Gradients were centrifuged in a SW28 rotor at $80000 \mathrm{~g}$ for $16-20 \mathrm{~h}$ at $4{ }^{\circ} \mathrm{C}$ in a Beckman ultracentrifuge. The inclusions sedimented as a distinct band at the interface between 67 and $72 \%$ sucrose. The band containing the inclusions was harvested from the gradients using a $10 \mathrm{ml}$ syringe and washed three times in ice-cold deionized water. The purity of the inclusions was confirmed by phase-contrast microscopy and the purified inclusions were stored at $-70^{\circ} \mathrm{C}$ in deionized water.

Cyt $\mathrm{A}$ inclusions were solubilized at $5-8 \mathrm{mg} \mathrm{ml}^{-1}$ by incubation at $37^{\circ} \mathrm{C}$ for $1 \mathrm{~h}$ in the presence of $10 \mathrm{mM}$ DTT in either $50 \mathrm{mM}$ $\mathrm{Na}_{2} \mathrm{CO}_{3}$ (pH 10.3) or deionized water adjusted to $\mathrm{pH} 12$ with $\mathrm{NaOH}$. Solubilized Cyt A was then separated from insoluble material by centrifugation at $12000 \mathrm{~g}$ for $15 \mathrm{~min}$.

Proteolytic processing of the solubilized CytA. The soluble CytA in $50 \mathrm{mM} \mathrm{Na}_{2} \mathrm{CO}_{3} / 10 \mathrm{mM}$ D'T (pH 10.3) was incubated at $37{ }^{\circ} \mathrm{C}$ with $5 \%(\mathrm{w} / \mathrm{w})$ trypsin (Sigma) or chymotrypsin (Sigma) or $0.5 \%$ (w/w) proteinase $\mathrm{K}$ (Sigma) overnight, or with 1 unit of $C$ ulex or Anopheles gut extract (Angsuthanasombat et al., 1992) per $25 \mu \mathrm{g}$ of soluble CytA for $2 \mathrm{~h}$. Cyt A was also treated with $10 \%(\mathrm{w} / \mathrm{w}$ ) insoluble proteinase $\mathrm{K}$ (proteinase $\mathrm{K}$ attached to agarose beads; Sigma). In this activation regime and prior to incubation with soluble Cyt A, the insoluble proteinase $\mathrm{K}$ was always washed by centrifugation in the solubilization buffer until no soluble protein was detected by measurement of
$A_{280}$ in the supernatant. The incubation was carried out at $37^{\circ} \mathrm{C}$ overnight with continuous gentle mixing. Following the activation, insoluble proteinase $\mathrm{K}$ was removed from the activated CytA by centrifugation at low speed $(1000 \mathrm{~g})$ and by filtration through a $0.20 \mu \mathrm{m}$ membrane filter (Sartorius). Activated CytA was stored at $4{ }^{\circ} \mathrm{C}$ or $-20^{\circ} \mathrm{C}$ until use.

Determination of protein concentrations. $\mathrm{Cyt} A$ concentration was determined by $A_{280}$ measurement based on the method of Cantor \& Schimmel (1980). For this assay it was estimated that an absorbance of 1.0 is equivalent to $1.0 \mathrm{mg} \mathrm{ml}^{-1}, 1.1 \mathrm{mg} \mathrm{ml}^{-1}$ and $1.2 \mathrm{mg} \mathrm{ml}^{-1}$ for soluble CytA, CytA activated with trypsin, and $C y t A$ activated with proteinase $K$, respectively. These values were compared with $C y t A$ concentrations determined by amino acid analysis and found to be within $\pm 10 \%$ of the above values.

Purification of CytA activated with trypsin or proteinase $K$ by fast protein liquid chromatography (FPLC). CytA activated with trypsin or proteinase $\mathrm{K}$ was purified by anion-exchange chromatography using a Mono $Q$ column (Pharmacia) connected to a Waters 650E-FPLC system (Millipore). The Mono Q column was equilibrated with $10 \mathrm{mM} \mathrm{NH} \mathrm{NHCO}_{3}$ (pH 8.5 adjusted with ammonia solution) and eluted at a flow rate of $1.0 \mathrm{ml} \mathrm{min}^{-1}$ with a gradient of $10-600 \mathrm{mM} \mathrm{NH}_{4} \mathrm{HCO}_{3}(\mathrm{pH}$ 8.5). Activated $\mathrm{CytA}$ and proteinase $\mathrm{K}$ samples were filtered through $0.20 \mu \mathrm{m}$ membranes prior to loading on the columns. Column effluents were monitored at $280 \mathrm{~nm}$ and $1.0 \mathrm{ml}$ fractions collected. Samples of protein peaks were analysed by SDSPAGE.

SDSPAGE. SDS-PAGE was carried out using the discontinuous Tris/glycine buffer system (Laemmli, 1970) as modified by Thomas \& Ellar (1983). Gels comprised a stacking gel of $6 \%$ $(\mathrm{w} / \mathrm{v})$ acrylamide and a separating gel of $13 \%(\mathrm{w} / \mathrm{v})$ acrylamide.

Protein samples in SDS sample buffer $[50 \mathrm{mM}$ Tris $/ \mathrm{HCl}(\mathrm{pH}$ 7.5), $1 \mathrm{mM}$ EDTA, $0.5 \%$ (w/v) SDS, $5 \%$ (v/v) glycerol, $0.05 \%$ (w/v) bromophenol blue, $25 \mathrm{mM}$ DTT] were boiled for $5 \mathrm{~min}$ at $100^{\circ} \mathrm{C}$ prior to loading onto the gels. Gels were stained for $1-2 \mathrm{~h}$ or overnight with Coomassie blue staining solution $[0 \cdot 1 \%(\mathrm{w} / \mathrm{v})$ Coomassie blue, $10 \%(\mathrm{v} / \mathrm{v})$ methanol, $10 \%(\mathrm{v} / \mathrm{v})$ acetic acid] and destained in $10 \%(\mathrm{v} / \mathrm{v})$ methanol $/ 10 \%(\mathrm{v} / \mathrm{v})$ acetic acid overnight at room temperature. Alternatively, gels were silver-stained using the method of Wray et al. (1981).

Protein molecular masses were estimated by comparison of $\log$ molecular mass to the relative mobility of protein molecular mass standards : $E$. coli $\beta$-galactosidase $(116 \mathrm{kDa})$, bovine serum albumin $(67 \mathrm{kDa})$, hen ovalbumin $(45 \mathrm{kDa})$, rabbit muscle glyceraldehyde phosphate dehydrogenase ( $36 \mathrm{kDa}$ subunit), bovine erythrocyte carbonic anhydrase $(29 \mathrm{kDa})$, trypsinogen $(24 \mathrm{kDa})$, soyabean trypsin inhibitor $(20 \mathrm{kDa})$, bovine milk $\alpha$ lactalbumin $(14 \mathrm{kDa})$.

$\mathbf{N}$-terminal protein sequencing. Proteins were subjected to SDS-PAGE with $0.015 \%(\mathrm{v} / \mathrm{v})$ thioglycollic acid in the electrophoresis buffer and then transferred onto Problot membranes (Applied Biosystems) using a semi-dry blot apparatus at a constant current. The transfer buffer consisted of $10 \mathrm{mM} \mathrm{3-}$ (cyclohexylamino)-1-propanesulfonic acid pH 6.5, 1 mM DTT and $10 \%$ methanol.

The blotted membrane was stained for 1-2 min with Coomassie staining solution and then destained in $50 \%(\mathrm{v} / \mathrm{v})$ methanol $/ 10 \%(\mathrm{v} / \mathrm{v})$ acetic acid for $10 \mathrm{~min}$. The membrane was briefly rinsed in deionized water and air dried. Stained bands were excised from the membrane and the proteins sequenced in an ABI 477A (Applied Biosystems) automated pulsed liquidphase sequencer. Sequence analysis was performed using 
standard RUN 477-1 software under the control of a $900 \mathrm{~A}$ data/controller module. The amino acid phenylthiohydantoin derivatives were analysed on line using a 120A PTH-amino acid analyser.

Amino acid analysis. Approximately $0.5-1 \mathrm{nmol}$ protein was lyophilized and hydrolysed at $110^{\circ} \mathrm{C}$ for $24 \mathrm{~h}$ in an argon atmosphere by the vapour from $6 \mathrm{M} \mathrm{HCl}$ containing $1 \%(\mathrm{v} / \mathrm{v})$ thioglycollic acid. Hydrolysed samples were analysed on a Pharmacia LKB Alpha Plus II amino acid analyser (sodium ionexchange system) using norleucine as an internal standard and ninhydrin complex detection.

In vitro haemolysis assays. Haemolysis assays were carried out as described by Thomas \& Ellar (1983) except that a $5 \%(\mathrm{v} / \mathrm{v})$ erythrocyte suspension in haemolysis buffer $[50 \%(\mathrm{w} / \mathrm{v})$ phosphate buffered saline (PBS; $\mathrm{pH} 7 \cdot 4$ ), $2 \cdot 25 \%$ (w/v) glucose, $0.1 \%(\mathrm{w} / \mathrm{v}$ ) gelatin] was used. Rat blood was collected in Alsevers solution $(0 \cdot 1 \mathrm{M}$ trisodium citrate, $40 \mathrm{mM}$ glucose) and stored at $4{ }^{\circ} \mathrm{C}$ until use. The erythrocytes were usually washed immediately before use with $50 \%(\mathrm{w} / \mathrm{v})$ PBS $/ 2 \cdot 25 \%(\mathrm{w} / \mathrm{v})$ glucose until all lysed cells were removed. The cells were then diluted in haemolysis buffer to make up the $5 \%(\mathrm{v} / \mathrm{v})$ erythrocyte suspension. The end-point of haemolysis was assessed after 3-12 h as the last well in which colouration of the liquid was still visible.

In vitro cytotoxicity assays against Aedes aegypti cells. The mosquito Aedes aegypti cell line used and its growth and maintenance conditions have been described previously (Knowles \& Ellar, 1986). Aedes aegypti cells (at 1-2 $\times 10^{6}$ cells $\mathrm{ml}^{-1}$ in tissue culture medium) were incubated at room temperature for 30,60 , and $120 \mathrm{~min}$ with $1 \mu \mathrm{g} \mathrm{ml}^{-1}$ of purified Cyt $\mathrm{A}$ activated with trypsin or proteinase $\mathrm{K}$. Controls containing equal volumes of buffer in which the test samples were originally suspended were also incubated with $A$. aegypti cells. Cell mortality was assessed by vital staining with $0 \cdot 1 \%(\mathrm{w} / \mathrm{v})$ Trypan blue in PBS buffer (Thomas \& Ellar, 1983). Cells were counted in a haemocytometer counting chamber.

\section{RESULTS}

\section{Solubilization and activation of cloned CytA crystals}

The crystals were solubilized at $5-8 \mathrm{mg} \mathrm{ml}^{-1}$ in $50 \mathrm{mM}$ $\mathrm{Na}_{2} \mathrm{CO}_{3} / \mathrm{HCl}(\mathrm{pH} 10 \cdot 3)$ with $10 \mathrm{mM}$ DTT at $37^{\circ} \mathrm{C}$ for $1 \mathrm{~h}$ and gave two bands with molecular masses of 23.5 and $27 \mathrm{kDa}$ on SDS-PAGE (Fig. 1, lane 3). In the absence of DTT, however, crystals were only about $20 \%$ soluble at $\mathrm{pH} 10 \cdot 3$. Crystals were also soluble in deionized water with $10 \mathrm{mM}$ DTT brought to $\mathrm{pH} 12$ by adding $\mathrm{NaOH}$. Unlike solubilization in sodium carbonate, this regime produced a single $27 \mathrm{kDa}$ band on SDS-PAGE (Fig. 1, lane 1), possibly as a result of inhibition of endogenous proteases by the higher $\mathrm{pH}$. When crystals were solubilized in SDS-sample buffer a predominant $24 \mathrm{kDa}$ band was seen (Fig. 1, lane 2), which suggested that the protein might have undergone $\mathrm{N}$-terminal processing during sample preparation. However, when this band was sequenced it had $\mathrm{N}$-terminal Met 1 while the alkalisolubilized CytA (Fig. 1, lane 3, lower band) had Val 26 as the N-terminal amino acid. This difference suggests that the SDS-solubilized crystals undergo C-terminal processing and/or that SDS solubilization causes the protein to migrate abnormally, as has been observed with CytB crystal protein (Koni \& Ellar, 1993).

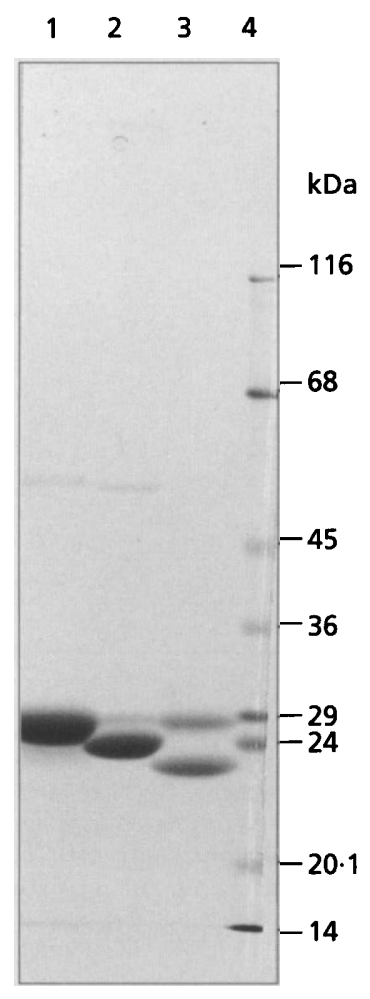

Fig. 1. Coomassie-Blue-stained SDS/13\% PAGE showing CytA solubilization under various conditions. Twenty micrograms of each sample in SDS sample buffer containing $25 \mathrm{mM}$ DTT, $5 \mathrm{mM}$ phenylmethylsulfonyl fluoride (PMSF) dissolved in 2-propanol, and $1 \mathrm{mM}$ EDTA were loaded per lane. Lane 1, CytA crystals solubilized in water/10 mM DTT adjusted to $\mathrm{pH} 12.0$ with $\mathrm{NaOH}$; lane 2, CytA crystals solubilized in SDS sample buffer; lane 3, CytA crystals solubilized in $50 \mathrm{mM} \mathrm{Na} \mathrm{CO}_{3} / 10 \mathrm{mM}$ DTT, pH 10.3; lane 4, molecular mass markers.

The alkali-soluble Cyt $\mathrm{A}$ was digested with a range of proteases to determine the pattern of activation. Chymotrypsin, trypsin, proteinase K, and Culex and Anopheles gut extracts were tested to find the enzyme producing the most effective cleavage of $\mathrm{Cyt} A$ with maximum retention of toxicity. SDS-PAGE revealed that $\mathrm{Cyt} A$ was processed to $24 \cdot 5-22 \mathrm{kDa}$ protease-resistant products by these regimes (Fig. 2). The products were sequenced from the $\mathrm{N}$-terminus to determine the site of cleavage and showed the pattern depicted in Table 1.

\section{Purification of trypsin- and proteinase-K-activated CytA products}

The soluble CytA activated with proteinase $K$ was subjected to ion-exchange chromatography and compared with Cyt A activated with trypsin according to the method of Chilcott \& Ellar (1988). CytA activated with $0.5 \%$ $(\mathrm{w} / \mathrm{w}$ ) proteinase $\mathrm{K}$ was applied to a Mono $\mathrm{Q}$ column equilibrated with $10 \mathrm{mM} \mathrm{NH}_{4} \mathrm{HCO}_{3}(\mathrm{pH} \mathrm{8.5)}$ and eluted with a $10-600 \mathrm{mM} \mathrm{NH} \mathrm{HCO}_{3}$ (pH 8.5) gradient. The $A_{280}$ trace (Fig. 3a, solid line) typically showed four peaks; the breakthrough (unretarded) peak, designated peak I, and three peaks in the middle of the gradient, 


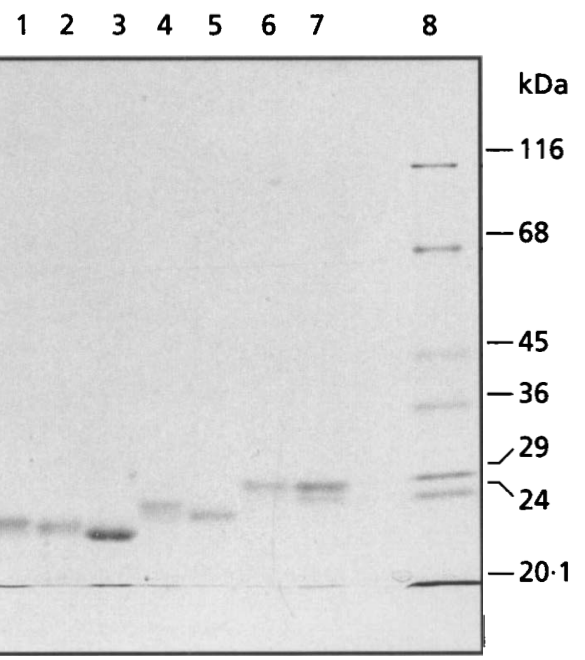

Fig. 2. Coomassie-Blue-stained SDS $/ 13 \%$ PAGE showing the pattern of CytA activation with various proteases. Soluble CytA

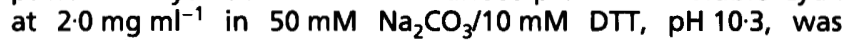
activated with $5 \%(\mathrm{w} / \mathrm{w})$ trypsin or chymotrypsin or $0.5 \%(\mathrm{w} / \mathrm{w})$ proteinase $\mathrm{K}$ at $37^{\circ} \mathrm{C}$ overnight, and with 1.0 unit of Culex or Anopheles gut extracts per $25 \mu \mathrm{g}$ of CytA for $2 \mathrm{~h}$ at $37^{\circ} \mathrm{C}$. Five microlitres of activated samples were mixed with $5 \mu$ l of $2 \times$ SDS sample buffer containing $25 \mathrm{mM}$ DTT, $5 \mathrm{mM}$ PMSF dissolved in 2-propanol, and $1 \mathrm{mM}$ EDTA. Samples were boiled for $5 \mathrm{~min}$ and $5 \mu \mathrm{l}$ was loaded per lane. Lanes 1-5, CytA treated with proteases: lane 1, Culex gut extract; lane 2, Anopheles gut extract; lane 3, proteinase $K$; lane 4, chymotrypsin; lane 5 , trypsin. Lane 6 , CytA solubilized in $50 \mathrm{mM} \mathrm{Na} \mathrm{CO}_{3} / 10 \mathrm{mM}$ DTT, $\mathrm{pH} 10.3$, at $4^{\circ} \mathrm{C}$; lane 7, CytA solubilized in $50 \mathrm{mM}$ $\mathrm{Na}_{2} \mathrm{CO}_{3} / 10 \mathrm{mM}$ DTT, $\mathrm{pH} 10 \cdot 3$, at $37^{\circ} \mathrm{C}$; lane 8 , molecular mass markers.

Table 1. N-terminal residue of CytA activated with various proteases

\begin{tabular}{|c|c|c|c|}
\hline $\begin{array}{l}\text { CytA } \\
\text { activated } \\
\text { with }\end{array}$ & $\begin{array}{l}\text { N-terminal } \\
\text { residue }\end{array}$ & $\begin{array}{c}\text { Approx. } \\
\text { size } \\
\text { (kDa) }\end{array}$ & $\begin{array}{c}\text { Figure } \\
\text { reference }\end{array}$ \\
\hline No activation & Met 1 & 27 & 1, lane 1 \\
\hline $\begin{array}{l}\text { Endogenous } \\
\text { proteases }\end{array}$ & $\begin{array}{c}\text { Val } 26, \text { Ile } 27 \\
\text { or Arg } 30\end{array}$ & $23 \cdot 5$ & $\begin{array}{l}\text { 1, lane } 3 \text {, } \\
\text { lower band }\end{array}$ \\
\hline Chymotrypsin & Lys 18 & $24 \cdot 5$ & 2 , lane 4 \\
\hline Trypsin & Val 26 & $23 \cdot 5$ & 2, lane 5 \\
\hline Proteinase $\mathrm{K}$ & $\begin{array}{l}\text { Arg } 30 \text { or } \\
\text { Val } 31\end{array}$ & 22 & 2, lane 3 \\
\hline $\begin{array}{l}\text { Anopheles gut } \\
\text { extract }\end{array}$ & $\begin{array}{l}\text { Arg } 30 \text { or } \\
\text { Val } 31\end{array}$ & $22 \cdot 5$ & 2, lane 2 \\
\hline Culex gut extract & $\begin{array}{l}\text { Arg } 30 \text { or } \\
\text { Val } 31\end{array}$ & $22 \cdot 5$ & 2, lane 1 \\
\hline
\end{tabular}

designated peaks II-IV (Fig. 3a). SDS-PAGE of fractions from these peaks showed that the activated CytA was in peaks III and IV, whilst peaks I and II contained no detectable protein (Fig. 3b). However, fraction 21 (F21) from peak III had an additional band at the dye front which was due to the presence of co-eluting proteinase $\mathrm{K}$. (Fig. 3a, dashed line). The purity of CytA activated with

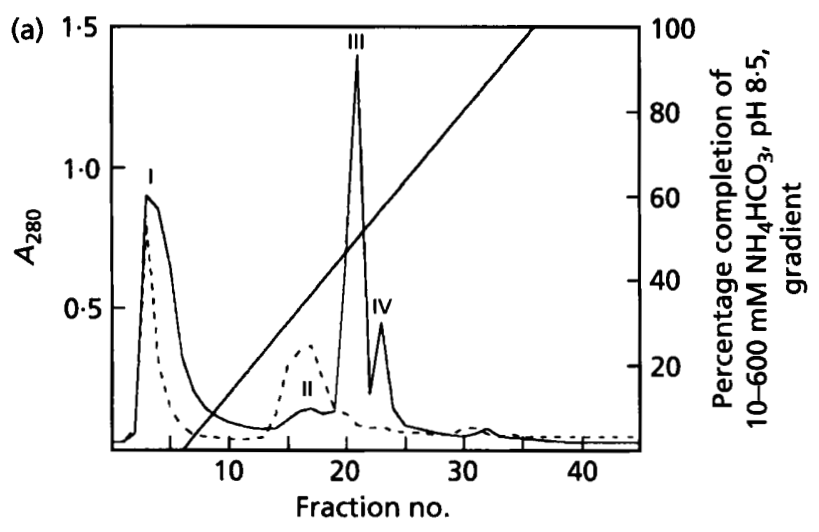

(b)

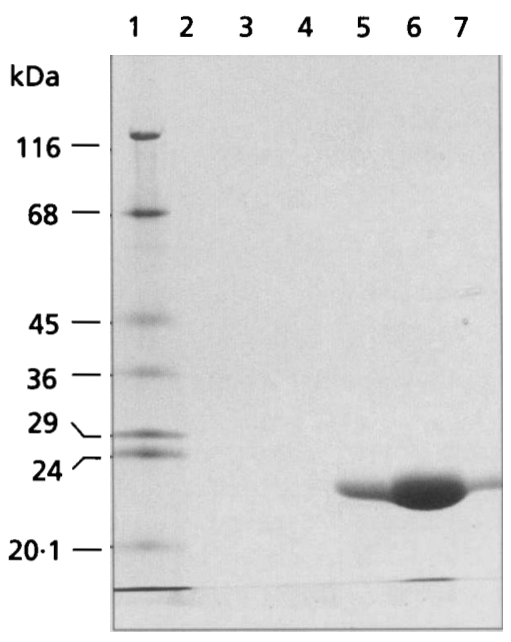

Fig. 3. (a) Purification of CytA activated with proteinase $K$ (solid line) and a control run containing only proteinase $K$ (dashed line) by FPLC using a Mono $Q$ column equilibrated with $10 \mathrm{mM} \mathrm{NH}_{4} \mathrm{HCO}_{3}, \mathrm{pH} 8.5$, and eluted with a $10-600 \mathrm{mM}$ $\mathrm{NH}_{4} \mathrm{HCO}_{3}, \mathrm{pH} 8.5$, linear gradient. Soluble CytA at $8.0 \mathrm{mg} \mathrm{ml}^{-1}$ in $50 \mathrm{mM} \mathrm{Na} \mathrm{CO}_{3} / 10 \mathrm{mM}$ DTT, pH 10.3, was activated with $0.5 \%$ $(w / w)$ proteinase $\mathrm{K}$ at $37^{\circ} \mathrm{C}$ for $6 \mathrm{~h}$. The sample was then adjusted to $10 \mathrm{mM} \mathrm{NH}_{4} \mathrm{HCO}_{3}, \mathrm{pH} 8.5$, before loading on the Mono Q column. Two milligrams of proteinase $\mathrm{K}$ was dissolved in $10 \mathrm{mM} \mathrm{NH}_{4} \mathrm{HCO}_{3}, \mathrm{pH} \mathrm{8.5}$, and loaded on the Mono Q column. Peaks are numbered with Roman numerals; flow rate $1.0 \mathrm{ml}$ $\mathrm{min}^{-1}$; fraction volume $1.0 \mathrm{ml}$. (b) Coomassie-Blue-stained SDS $/ 13 \%$ PAGE analysis of fractions from Mono $Q$ column chromatography of CytA activated with proteinase $K$ ( $a$, solid line). Twenty-five microlitres of each fraction were mixed with an equal volume of $2 \times$ SDS sample buffer and boiled for $5 \mathrm{~min}$ before loading. Lane 1, molecular mass markers; lane 2, fraction 5; lane 3, fraction 10; lane 4, fraction 16; lane 5, fraction 20; lane 6, fraction 21; lane 7, fraction 24.

proteinase $\mathrm{K}$ was greatly improved when insoluble proteinase $\mathrm{K}\left(10 \% \mathrm{w} / \mathrm{w}, 37^{\circ} \mathrm{C}\right.$, overnight $)$ was used for the activation and the Mono $Q$ column eluted with a step gradient as shown in Fig. 4(a). A silver stained SDSPAGE of fractions from this step gradient run is shown in Fig. 5 (lanes 6-9).

Although activated CytA was resolved into three separable peaks on the column, SDS-PAGE showed that fractions 24 and 25 (F24 and F25) from peak III and F37 from peak $\mathrm{V}$ had the same size band at about $22 \mathrm{kDa}$, while F30 from peak IV had a band of approximately 

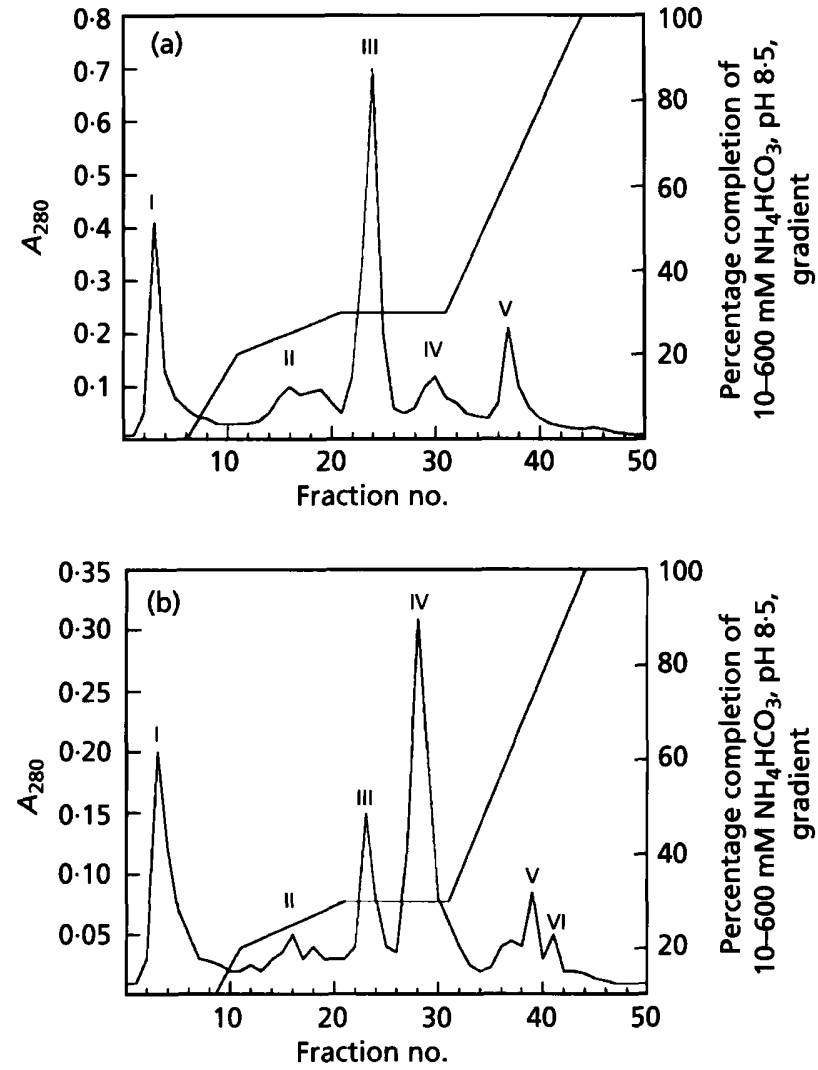

Fig. 4. Purification of CytA activated with proteinase $K$ (a) or trypsin (b) by FPLC using a Mono $Q$ column, equilibrated with $10 \mathrm{mM} \mathrm{NH}_{4} \mathrm{HCO}_{3}, \mathrm{pH} 8.5$, and eluted with a $10-600 \mathrm{mM}$ $\mathrm{NH}_{4} \mathrm{HCO}_{3}, \mathrm{pH} \mathrm{8.5}$, step gradient. Soluble CytA at $5.0 \mathrm{mg} \mathrm{ml}^{-1}$ in $50 \mathrm{mM} \mathrm{Na} 2 \mathrm{CO}_{3} / 10 \mathrm{mM}$ DTT, pH $10 \cdot 3$, was activated with $10 \%$ $(w / w)$ insoluble proteinase $\mathrm{K}$ or with $1 \%(w / w)$ trypsin at $37^{\circ} \mathrm{C}$, overnight. The samples were adjusted with equilibration buffer before loading on the Mono Q column. Peaks are numbered with Roman numerals; flow rate $1.0 \mathrm{ml} \mathrm{min}^{-1}$; fraction volume $1.0 \mathrm{ml}$. $\begin{array}{llllllllll}10 & 9 & 8 & 7 & 6 & 5 & 4 & 3 & 2 & 1\end{array}$

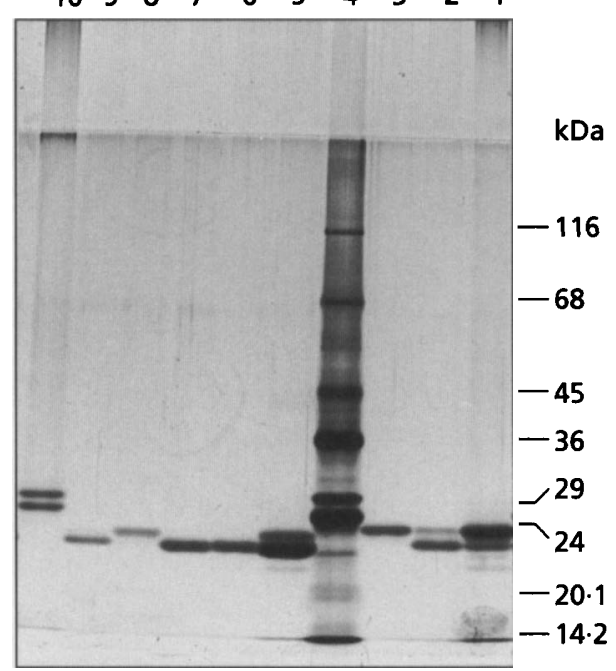

Fig. 5. Silver-stained SDS/13\% PAGE analysis of fractions from Mono $Q$ column chromatography of CytA activated with proteinase $K$ and trypsin (Fig. $4 a$, b). One microgram of sample in SDS sample buffer containing $25 \mathrm{mM}$ DTT was loaded per lane. Lane 1, soluble CytA activated with $1 \%(w / w)$ trypsin at $37^{\circ} \mathrm{C}$, overnight; lanes 2 and 3 , samples from fractions 24 and 28 , respectively, of the trypsin run (Fig. 4b); lane 4, molecular mass markers; lane 5 , soluble CytA activated with $10 \%(\mathrm{w} / \mathrm{w})$ insoluble proteinase $K$ at $37^{\circ} \mathrm{C}$, overnight; lanes $6-9$, samples from fractions $24,25,30$ and 37 , respectively, of the proteinase $\mathrm{K}$ run (Fig. 4a); lane 10, soluble CytA in $50 \mathrm{mM} \mathrm{Na}_{2} \mathrm{CO}_{3} / 10 \mathrm{mM}$ DTT, pH 10.3.

Table 2. Haemolytic assay of different forms of CytA

\begin{tabular}{|c|c|c|c|c|}
\hline Sample & $\begin{array}{l}\text { N-terminal } \\
\text { residue }\end{array}$ & $\begin{array}{l}\text { Approx. } \\
\text { size (kDa) }\end{array}$ & $\begin{array}{l}\text { Lane in } \\
\text { Fig. } 5\end{array}$ & $\begin{array}{l}\text { Approx. concn } \\
\left(\mu \mathrm{g} \mathrm{ml}^{-1}\right) \text { at } \\
\text { end-point } \\
\text { haemolysis }\end{array}$ \\
\hline $\begin{array}{l}100 \mathrm{mM} \mathrm{NH}_{4} \mathrm{HCO}_{3}, \mathrm{pH} 8.5 \\
\text { or } 50 \mathrm{mM} \mathrm{Na}_{2} \mathrm{CO}_{3} / 10 \mathrm{mM} \\
\text { DTT, pH } 10.3\end{array}$ & - & - & - & No haemolysis \\
\hline Soluble CytA & $\begin{array}{c}\text { Met } 1 \text { or } \\
\text { Val } 26\end{array}$ & $27-23.5$ & 10 & $2 \cdot 3$ \\
\hline F28 of trypsin run & Val 26 & $23 \cdot 5$ & 3 & $2 \cdot 3-1 \cdot 2$ \\
\hline F24 of proteinase $\mathrm{K}$ run & Arg 30 & 22 & 6 & 0.6 \\
\hline $\begin{array}{l}\text { F28 of trypsin run mixed } \\
\text { with F24 of proteinase K } \\
\text { run }\end{array}$ & & & & 0.6 \\
\hline F30 of proteinase $\mathrm{K}$ run & $\operatorname{Arg} 30$ & 23 & 8 & $2 \cdot 3-1 \cdot 2$ \\
\hline F37 of proteinase $\mathrm{K}$ run & Val 31 & 22 & 9 & 0.6 \\
\hline
\end{tabular}



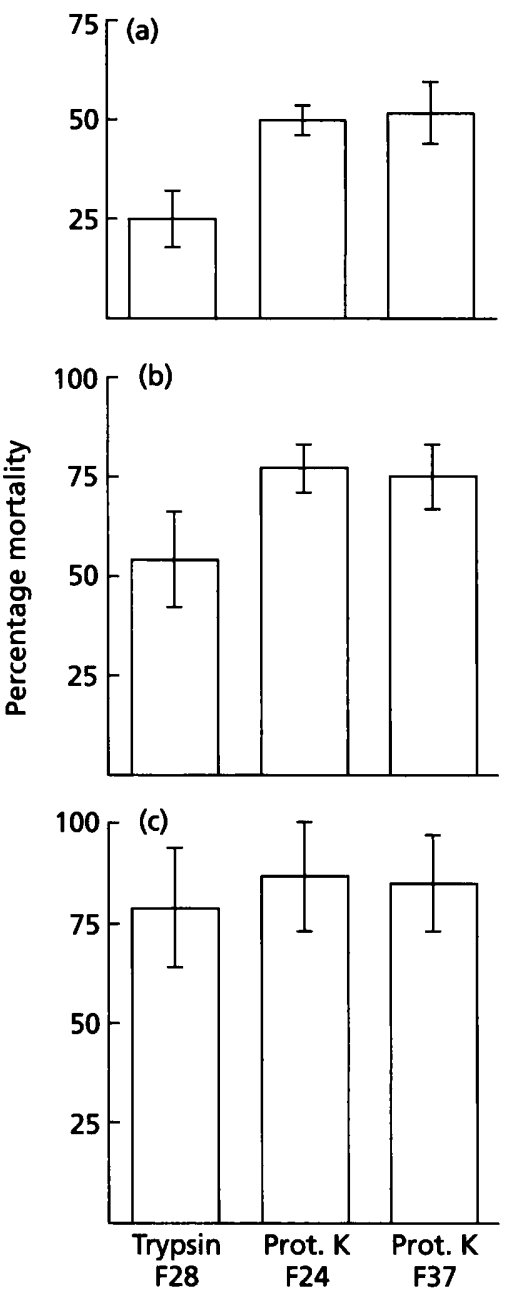

Fig. 6. Toxicity assay against the mosquito cell line Aedes aegypti, using CytA activated with trypsin and proteinase $K$ and purified by Mono Q column chromatography (Figs 4 and 5). To $47.5 \mu \mathrm{l}$ of cell suspension (1.0-1.5 $\times 10^{6}$ cells $\left.\mathrm{ml}^{-1}\right), 2.5 \mu \mathrm{l}$ of toxin solution $\left(20 \mu \mathrm{g} \mathrm{ml}^{-1}\right)$ was added to give a final concentration of $1.0 \mu \mathrm{g} \mathrm{ml}^{-1}$. Cells were incubated with the toxin at room temperature for 30 (a), 60 (b), and 120 (c) min before being counted using Trypan blue staining. Error bars (mean $\pm S E M$, $n=3$ ) are based on three separate experiments. The mortality in control cells incubated with equal volumes of buffer rarely exceeded 10-15\%; these values have been subtracted in the Figure.

$23.5 \mathrm{kDa}$. The $\mathrm{N}$-terminal sequence of these fractions revealed that the $\mathrm{N}$-terminal residue of F24, F25 and F30 was Arg 30 while F37 had Val 31 as its N-terminal amino acid. Since $\mathrm{F} 30$ had a higher molecular mass band than F24, F25 and F37, this suggests that the product in F24, F25 and F37 was probably processed from both termini (for further details see Discussion).

Comparison of the elution profile of CytA activated with proteinase $\mathrm{K}$ with that of trypsin-activated CytA under the same chromatography conditions showed that the trypsin product was resolved into two peaks and trypsin was eluted in an earlier fraction than proteinase $K$ (Fig. 4b). Silver-stained SDS-PAGE revealed that the lower band of trypsin fraction 24 (F24) ran at about the same

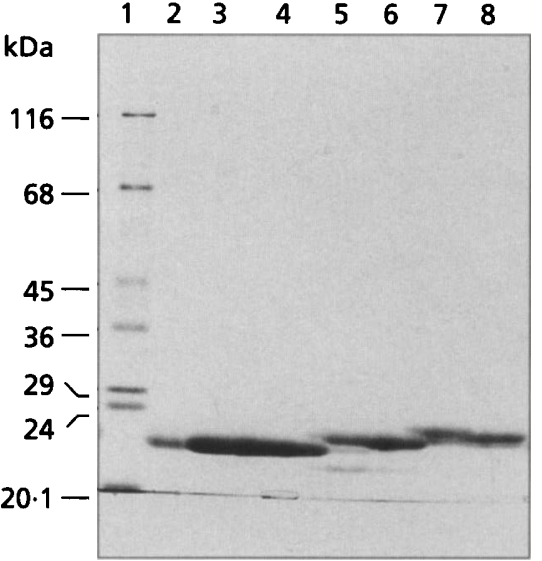

Fig. 7. Coomassie-Blue-stained SDS/13\% PAGE showing the pattern after a second round of activation of the purified fractions from the trypsin and proteinase $K$ runs from the Mono $\mathrm{Q}$ column (Fig. 4). Approximately $20 \mu \mathrm{g}$ of each sample in SDS sample buffer containing $25 \mathrm{mM}$ DTT, $5 \mathrm{mM}$ PMSF and $1 \mathrm{mM}$ EDTA was loaded per lane. Lane 1, molecular mass markers; lane 2, fraction 24 of the proteinase $K$ run; lanes 3-5, fraction 24 of the proteinase $K$ run treated respectively with $0.5 \%(w / w)$ proteinase K, 5\% (w/w) chymotrypsin, 5\% (w/w) trypsin at $37^{\circ} \mathrm{C}$, overnight; lanes $6-8$, fraction 28 of the trypsin run treated respectively with $0.5 \%(w / w)$ proteinase $K, 5 \%(w / w)$ chymotrypsin, $5 \%(w / w)$ trypsin at $37^{\circ} \mathrm{C}$, overnight; lane 9, fraction 28 of the trypsin run.

position as F24 of proteinase K (Fig. 5, lanes 2 and 6, respectively) while trypsin F28 ran at higher molecular mass than proteinase K F24 (Fig. 5, lanes 3 and 6, respectively). However, both F24 and F28 of the trypsin product had Val 26 as their $\mathrm{N}$-terminal amino acid. It is probable that the F24 toxin (Fig. 5, lane 2, lower band) from trypsin-activated Cyt $\mathrm{A}$, like the proteinase $\mathrm{K}$ activated F24 toxin, was also processed from both termini (see Discussion).

\section{Haemolytic and cytolytic assays}

The enzymic cleavage products of CytA were further characterized by comparing their toxicity. CytA is haemolytic and a haemolysis assay is a simple and convenient means of testing the products. Samples of alkali-soluble Cyt $A$ and $C y t A$ processed with various proteases were assayed against rat erythrocytes as described in Methods. The haemolytic activity decreased in the following order: proteinase $\mathrm{K}$ product $>$ trypsin product $>$ chymotrypsin product $=$ soluble $\mathrm{CytA}$. This pattern was confirmed when fractions obtained from the Mono $Q$ column were assayed. The F24 and F37 from the proteinase $\mathrm{K}$ run were the most haemolytic followed by trypsin F28, while soluble CytA was the least haemolytic (Table 2). It is interesting to note that the most haemolytic of the samples tested was also the smallest.

The F24 and F37 from proteinase $\mathrm{K}$ activation and F28 from trypsin activation runs were also assayed against an Aedes aegypti cell line. The results indicated that the proteinase K F24 and F37 were more toxic than trypsin 
F28. In fact, the proteinase K F24 and F37 were twice as toxic as trypsin F28 after 30 min incubation (Fig. 6a). The difference in toxicity, however, became progressively less as the time of incubation increased (Fig. 6b, c). This was possibly due to lysis of cells before being counted and/or the smaller CytA product being able to form a pore at a faster rate.

\section{DISCUSSION}

Thomas \& Ellar (1983) found that CytA toxin could be selectively dissolved from native Bti crystals without DTT. By contrast, when the cyt $A$ gene was expressed with the $20 \mathrm{kDa}$ 'helper' protein gene in Bti IPS 78/11 the large lemon-shaped inclusions that were formed (Crickmore $e$ t al., 1990) were only soluble at $\mathrm{pH} 10 \cdot 3-10.5$ with the addition of $10 \mathrm{mM}$ DTT as a reducing agent. It is difficult to explain this difference in CytA solubility between the native and cloned $\mathrm{Cyt} A$ inclusions. Cyt $\mathrm{A}$ contains two cysteine residues (Ward \& Ellar, 1986) and it is possible that intermolecular disulfide bonds can form when Cyt $A$ is synthesized and packed into inclusions in the absence of the other Bti toxins. The $20 \mathrm{kDa}$ 'helper' protein has four cysteine residues (Adams et al., 1989) and could possibly also be involved in disulfide bonding with CytA. However, the $20 \mathrm{kDa}$ 'helper' protein could only be detected immunologically at very high gel loading in native Bti inclusions (Adams et al., 1989) and could not be detected in the cloned CytA inclusions by Coomassie staining (S. Al-yahyaee, unpublished result). Nevertheless, some role for the $20 \mathrm{kDa}$ 'helper' protein in the formation of disulfide bridges in the cloned CytA inclusion is suggested by the observation that the cloned CytA inclusions produced in B. subtilis (Ward et al., 1986; Armstrong, 1992) without the $20 \mathrm{kDa}$ 'helper' protein, are soluble in the absence of DTT.

During solubilization, CytA is processed by endogenous proteases to $24 \cdot 5-22 \mathrm{kDa}$ products (data not shown). This processing can be mimicked by incubating soluble CytA with proteases such as trypsin and proteinase $K$. Trypsin cleaves Cyt A at $\operatorname{Arg} 25$, which is in agreement with the report by Chilcott \& Ellar (1988). However, trypsinactivated products purified by Mono $\mathrm{Q}$ ion-exchange chromatography were resolved into two peaks (Fig. 4b) and when checked on SDS-PAGE, two products were seen which differed by about $2.0 \mathrm{kDa}$, although both had Val 26 as their $\mathrm{N}$-terminal residue (Fig. 5, lanes 2 and 3). Similarly, SDS-PAGE analysis of proteinase $\mathrm{K}$ products purified by the Mono $Q$ column showed two different molecular mass products (Fig. 5, lanes 7 and 8), both of which had Arg 30 as their N-terminal amino acid. These data suggest that trypsin and proteinase $\mathrm{K}$ each process Cyt A from both termini. Position 225 of Cyt A seems to be a potential cleavage site for proteinase $\mathrm{K}$ and trypsin at the C-terminus. This site has the sequence Leu 224-Lys 225-Phe 226-, which is structurally equivalent to the proteinase K cleavage site Leu 29-Arg 30-Val 31- at the $\mathrm{N}$-terminus. Furthermore, in the former sequence Lys 225 can serve as a potential cleavage site for trypsin. In fact, when trypsin-treated F28 was treated with proteinase K and chymotrypsin (with Phe 226 as a potential cleavage site) (Fig. 7, lanes 6 and 7, respectively) it produced a band on SDS-PAGE equivalent to that of trypsin F24 (Fig. 5, lane 2, lower band), while proteinase-K-treated F24 showed no difference in size after being treated with trypsin and chymotrypsin (Fig. 7, lanes 4 and 5). If both trypsin and proteinase $\mathrm{K}$ process $\mathrm{Cyt} A$ at the same position from the $\mathrm{C}$-terminus, then the difference in molecular mass between trypsin-treated F24 and proteinase-K-treated F30 (Fig. 5, lanes 3 and 8, respectively), both of which were only N-terminally processed, can be attributed to the 5 amino acid difference at the $\mathrm{N}$-terminus. Furthermore, the difference in molecular mass between the whole Cyt $\mathrm{A}(27 \cdot 4 \mathrm{kDa})$ and proteinaseK-treated F24 $(22 \mathrm{kDa})$ can be accounted for by the removal of a total of about 55 amino acids from both termini. In summary, the data above provide experimental evidence to support the argument that $\mathrm{Cyt} A$, like $\mathrm{CytB}$ (Knowles et al. , 1992; Koni \& Ellar, 1994) and Cry toxins (Hofte \& Whiteley, 1989) is processed from both termini.

Soluble CytA, unlike CytB (Koni \& Ellar, 1993) and Cry toxins (Hofte \& Whiteley, 1989), is probably active without prior processing. However, the high susceptibility of the CytA N-terminus to endogenous proteases hindered previous attempts to assay the unprocessed CytA. The $\mathrm{N}$-terminal processing can be minimized if Cyt A crystals are solubilized at $\mathrm{pH} 12$ with $10 \mathrm{mM}$ DTT, as shown in Fig. 1, lane 1. When this sample was assayed against rat erythrocytes it was found to be as haemolytic as processed soluble CytA in $\mathrm{Na}_{2} \mathrm{CO}_{3}, \mathrm{pH} \mathrm{10.3} \mathrm{(data} \mathrm{not}$ shown). While this result may imply that $\mathrm{N}$-terminal processing is not necessary for toxicity, it is possible that the minor processed product seen in front of the main $27 \mathrm{kDa}$ band was responsible for toxicity. In fact when this sample was applied to a Mono $Q$ column equilibrated with $10 \mathrm{mM} \mathrm{NH} \mathrm{NHCO}_{3}(\mathrm{pH} \mathrm{8.5)}$ and eluted with a 10-600 mM $\mathrm{NH}_{4} \mathrm{HCO}_{3}$ (pH 8.5) linear gradient, the protein was collected in a single broad peak (data not shown), which suggested that the sample was heterogeneous in composition, possibly as a result of differentially processed components.

A comparative toxicity study of CytA processed with various proteases established that the $22 \mathrm{kDa}$ proteinase $\mathrm{K}$ product was the most active both against rat erythrocytes (Table 2) and Aedes aegypti cells (Fig. 6). A similar observation was reported by Gill et al. (1987), whose $24 \mathrm{kDa}$ product was more active than the $25 \mathrm{kDa}$ product. Their $24 \mathrm{kDa}$ product is probably equivalent to the $22 \mathrm{kDa}$ product reported here since both had the same $\mathrm{N}$-terminus, but they used different molecular mass markers to estimate the size. If the $22 \mathrm{kDa}$ proteinase $\mathrm{K}$ product was processed from both termini, it is feasible that the enhanced toxicity was as a result of either differential $\mathrm{N}$-terminal and/or $\mathrm{C}$-terminal processing. For instance, the difference in toxicity between soluble Cyt $\mathrm{A}$ and the N-terminally processed trypsin-treated F28 (see Table 2) can be attributed to the N-terminal processing, based on the assumption that soluble $\mathrm{CytA}$ was only partially processed (Fig. 1, lane 3). However, the following observations support the hypothesis that Cterminal processing was responsible for the further 
increase in toxicity. First, when the proteinase-K-treated products F24 and F30 with the same N-terminus, but different molecular masses, were assayed against rat erythrocytes it was found that F24 was at least twofold more haemolytic than F30 (Table 2). Second, the same assay showed that the $22 \mathrm{kDa} F 24$ and F37 were equally haemolytic even though they had different $\mathrm{N}$-termini (Table 2). Third, the $22 \mathrm{kDa}$ F24 from trypsin digestion was more cytolytic to the Aedes aegypti cell line than the $24 \mathrm{kDa}$ F28, although both products had the same Nterminus (data not shown). In the light of the results above it is clear that processing at both termini contributes to the increase in toxicity. Unfortunately since it was not possible to produce a CytA derivative processed only from the $\mathrm{C}$-terminus, the relative contribution of the $\mathrm{C}$ terminal processing of this toxin cannot be assessed. Although the results discussed above were from in vitro experiments, a CytA product with a similar size to the $22 \mathrm{kDa}$ proteinase $\mathrm{K}$ product and same $\mathrm{N}$-terminus was obtained when mosquito gut extract was used to activate soluble CytA (Fig. 2, lanes 1 and 2). This suggested that the extent of processing is probably the same in the mosquito gut and hence the $22 \mathrm{kDa}$ protein is the most active. Therefore, it appears that CytA, like other Bt $\delta$ endotoxins, is processed to a well-defined proteaseresistant product and this processing enhances the toxicity both in vitro and in vivo.

\section{ACKNOWLEDGEMENTS}

This work was supported by a scholarship from Sultan Qaboos University (Muscat, Sultanate of Oman) and an Overseas Research Award Scheme from the British government (S. A.S. A.) and by the Agriculture and Food Research Council (D. J. E.). We thank Dr Neil Crickmore for critical review of the manuscript, and Trevor Sawyer and Mary George for excellent technical assistance.

\section{REFERENCES}

Adams, L. F., Visick, J. E. \& Whiteley, H. R. (1989). A 20-kilodalton protein is required for efficient production of the Bacillus thuringiensis subsp. israelensis 27-kilodalton crystal protein in Escherichia coli. J. Bacteriol 171, 521-530.

Angsuthanasombat, C., Crickmore, N. \& Ellar, D. J. (1992). Comparison of Bacillus thuringiensis subsp. israelensis CryIVA and CrylVB cloned toxins reveals synergism in vivo. FEMS Microbiol Lett 94, 63-68.

Armstrong, G. (1992). Directed mutagenesis of the Cyt A delta-endotoxin of Bacillus thuringiensis ssp. israelensis. $\mathrm{PhD}$ thesis, University of Cambridge, UK.

Armstrong, J. L., Rohrmann, G. F. \& Beaudreau, G. S. (1985). Delta endotoxin of Bacillus thuringiensis subsp. israelensis. J Bacteriol 161, $39-46$.

Cantor, C. R. \& Schimmel, R. R. (1980). Biophysical Chemistry, part II, Techniques for the Study of Biological Structure and Function. San Francisco: W. H. Freeman.

Chilcott, C. N. \& Ellar, D. J. (1988). Comparative toxicity of Bacillus thuringiensis var. israelensis crystal proteins in vivo and in vitro. J Gen Microbiol 134, 2551-2558.

Crickmore, N., Bone, E. J. \& Ellar, D. J. (1990). Genetic manipulation of Bacillus thuringiensis: towards an improved pesticide. Aspects Appl Biol 24, 17-24.
Ellar, D. J. \& Posgate, J. A. (1974). Characterisation of forespores isolated from Bacillus megaterium at different stages of development into mature spores. In Spore Research, pp. 21-40. Edited by A. N. Barker, G. W. Gould \& J. Wolf. London: Academic Press.

Gill, S. S., Singh, G. J. P. \& Hornung, J. M. (1987). Cell membrane interaction of Bacillus thuringiensis subsp. israelensis cytolytic toxins. Infect Immun 55, 1300-1308.

Goldberg, L. J. \& Margalit, J. (1977). A bacterial spore exhibiting larvicidal activity against Anopheles sergentii, Uranotaenia unguiculata, Culex univitattus, Aedes aegypti and Culex pipiens. Mosq News 37, 355-358.

Hofte, H. \& Whiteley, H. R. (1989). Insecticidal crystal proteins of Bacillus thuringiensis. Microbiol Rev 53, 242-255.

Knowles, B. H. \& Ellar, D. J. (1986). Characterisation and partial purification of a plasma membrane receptor for Bacillus thuringiensis var. kurstaki lepidopteran-specific $\delta$-endotoxin. J Cell Sci 83, 89-101.

Knowles, B. H., White, P. J., Nicholls, C. N. \& Ellar, D. J. (1992). A broad spectrum cytolytic toxin from Bacillus thuringiensis var. kyushuensis. Proc $R$ Soc Lond B 248, 1-7.

Koni, P. A. \& Ellar, D. J. (1993). Cloning and characterisation of a novel Bacillus thuringiensis cytolytic delta-endotoxin. J Mol Biol 229, 319-327.

Koni, P. A. \& Ellar, D. J. (1994). Biochemical characterization of Bacillus thuringiensis cytolytic $\delta$-endotoxins. Microbiology 140, 1869-1880.

Laemmli, U. K. (1970). Cleavage of structural proteins during the assembly of the head of bacteriophage T4. Nature 227, 680-685.

Sambrook, J., Fritsch, E. F. \& Maniatis, T. (1989). Molecular Cloning: a Laboratory Manual, 2nd edn. Cold Spring Harbor, NY: Cold Spring Harbor Laboratory.

Stewart, G. S. A. B., Johnstone, K., Hagelberg, E. \& Ellar, D. J. (1981). Commitment of bacterial spores to germinate. Biochem J 198, 101-106.

Thomas, W. E. \& Ellar, D. J. (1983). Bacillus thuringiensis var. israelensis crystal $\delta$-endotoxin: effects on insect and mammalian cells in vitro and in vivo. J Cell Sci 60, 181-197.

Tyrell, D. J., Bulla, L. A., Andrews, R. E., Kramer, K. J., Davidson, L. I. \& Nordin, P. (1981). Comparative biochemistry of entomocidal parasporal crystals of selected Bacillus thuringiensis strains. J Bacteriol 145, 1052-1062.

Ward, E. S. \& Ellar, D. J. (1986). Bacillus thuringiensis var. israelensis $\delta$ endotoxin: nucleotide sequence and characterisation of the transcripts in Bacillus thuringiensis and Escherichia coli. J Mol Biol 191, 1-11.

Ward, E. S., Todd, A. J. \& Ellar, D. J. (1984). Cloning and expression in Eschericbia coli of the insecticidal $\delta$-endotoxin gene of Bacillus thuringiensis var. israelensis. FEBS Lett 175, 377-382.

Ward, E. S., Ridley, A. R., Ellar, D. J. \& Todd, J. A. (1986). Bacillus thuringiensis var. israelensis $\delta$-endotoxin: cloning and expression of the toxin in sporogenic and asporogenic strains of Bacillus subtilis. $J$ Mol Biol 191, 13-22.

Ward, E. S., Ellar, D. J. \& Chilcott, C. N. (1988). Single amino acid changes in the Bacillus thuringiensis var. israelensis $\delta$-endotoxin affect the toxicity and expression of the protein. $J$ Mol Biol 202, 527-535.

Wray, W., Boulikas, T., Wray, V. \& Hancock, R. (1981). Silver staining of proteins in polyacrylamide gels. Anal Biochem 118, 197-203.

Received 28 February 1995; revised 25 July 1995; accepted 11 August 1995. 